Island Studies Journal, Vol. 2, No. 2, 2007, pp. 209-228

\title{
Industrial Development in an Island Economy: US Trade Policy and Canned Tuna Production in American Samoa
}

\author{
Liam Campling \\ PhD Candidate, Department of Development Studies \\ School of Oriental and African Studies (SOAS) \\ University of London, United Kingdom \\ liamcampling@yahoo.co.uk
}

$\&$

Elizabeth Havice

PhD Candidate, Department of Environmental Science, Policy \& Management

University of California-Berkeley CA, USA

ehavice@nature.berkeley.edu

\begin{abstract}
It is widely argued that small states and territories have relied upon the strategic trade and economic policies of larger countries to achieve development goals. Using the case of the export-oriented tuna industry in American Samoa (a territory of the United States), we argue that its status as a sub-national island jurisdiction (SNIJ) has been essential in jumpstarting and supporting industrial development. However, this relationship and its associated benefits are just one set of factors that influence the economic development opportunities and constraints that American Samoa's tuna industry faces in the contemporary world economy. Moreover, the maintenance and future possibilities for industrial development in both SNIJs and (arguably) more economically vulnerable sovereign small developing island states (SIDS), is increasingly unlikely in the context of a globalizing capitalism and the new international trade regime.
\end{abstract}

Keywords: American Samoa, canned tuna, US trade policy, Pacific Ocean, preferential market access, economic globalization, sub-national island jurisdictions.

Copyright (C) 2007 Institute of Island Studies, University of Prince Edward Island, Canada.

\section{Introduction: Industrial Development in Small Island Developing Territories}

Small island developing states (SIDS) and island territories with political ties to developed countries (small sub-national island jurisdictions, SNIJs) have long been identified for the difficulties they face in sustaining successful export-oriented industries. Although many such territories are resource rich, their industrialization strategies and private sectors are often at a distinct disadvantage from the outset as a result of diseconomies of scale, challenging environmental conditions, fluctuating commodity prices, difficulty in accessing markets, lack of adequate infrastructure (including water and power) and high 
labour and transit costs (Armstrong \& Read, 2006; Baldacchino, 1998; Demas, 1965). ${ }^{1}$ In fact, the empirical evidence points to the conclusion that, at least in some cases, these factors create an inherent condition of non-competitiveness for small and remote economies in the world economy (Winters \& Martin, 2004).

Indeed, recent research led by L. Alan Winters has demonstrated quantitatively that small remote economies ${ }^{2}$ suffer from higher costs of doing business (Winters \& Martins, 2004; Winters, 2005). Moreover, this work demonstrates that the mainstream economic theory of comparative advantage "is not enough" to counter their associated "combination of diseconomies of small scale and high transaction costs" in practice; not least "as globalization proceeds and their current trade preferences are eroded” (Winters \& Martins, 2004:347). In short, what Winters suggests is that people living in small island territories “... face such great absolute disadvantages that exporting at world prices is either impossible or generates factor incomes that are too low to subsist. In the limit, free trade could mean no trade for these economies" (ibid.: 348, emphasis added). ${ }^{3}$ The evidence of Winters \& Martins serves to support the argument that small developing island states and sub-national island jurisdictions "suffer from volatilities associated with their permanent geographical isolation and associated extreme economic vulnerability" (Campling, 2006:254-5, after Hache, 1998).

Along these lines, Winters \& Martins' policy conclusions - stemming from (and constrained by) the assumptions of mainstream economics - are bleak. They suggest that government policy interventions, from tariff protection through to subsidies, are not advisable strategies for achieving industrialization objectives. Instead, they argue that small states should "economize on the costs of economic management or even of statehood" (2004:376), ignoring a wide body of academic evidence since the late 1980s on the integral role of state intervention in economic development (see, for example, Amsden, 1989; Chang, 2004; Wade, 1990). They are, however, realistic enough to recognize that such efficiency gains would be insufficient to sustain small remote economies and state that "ultimately the international community will have to provide the compensating flows" (Winters \& Martins, 2004:377), positioning SIDS and SNIJs for a future of complete economic dependence on overseas development assistance.

On the other hand, a second strand of research argues that small island economies, particularly the subset of SNIJs, have achieved higher levels of economic performance and private sector development relative to most other larger (mainly continental) developing states and sovereign island economies (Armstrong \& Read, 2000, 2002; Bertram, 2004;

\footnotetext{
${ }^{1}$ There is a large literature on SIDS and their perceived 'vulnerabilities', and there is an associated longrunning debate on the extent to which SIDS have specific economic characteristics relative to other small developing economies beyond the notion of 'islandness'. For a critical overview of this debate (including on how the categorization of SIDS vulnerabilities has changed over time) see Campling (2006). On the exclusion of 'social' aspects in contemporary SIDS discourse, see Campling \& Rosalie (2006).

${ }^{2}$ Winters \& Martins (2004) focus on several of the different economic impacts of both 'smallness' and 'remoteness', recognizing that the two factors have different impacts on economic growth.

${ }^{3}$ They go on to conclude that: "These economies will not be suitable locations for industry or even tourism unless they have very specific advantages that allow them to charge substantially higher prices than the median country” (Winters \& Martins, 2004:376).
} 
McElroy \& Pearce, 2006; Poirine, 1998). Drawing on the benefits that arise from strategic political relations - such as trade and other preferences - and refusing sovereignty in favour of a more cautious veiled political autonomy, SNIJs have arguably strengthened, if far from completely insulated, their international economic competitiveness and political stability (Baldacchino, 2006a). Where small island territories have political ties to economically larger and more powerful countries, they often draw upon extra-territorial resources, such as goods and services as well as access to legal infrastructure, a stable currency, diplomatic and military relations, and market access in order to overcome the challenging economic and political climate that typifies most small remote economies (Baldacchino, 2006b; Winters \& Martins, 2004). As a result, SNIJs often display more success and stability than other sovereign island economies (Baldacchino, 2006c).

Despite the apparent (and relative) success of SNIJs, both Baldacchino (2006a) and Winters \& Martins (2004) refrain from declaring autonomy with links to developed countries the cure-all to the economic challenges of capitalist development in small remote economies. Rather, the former notes that the economic success of autonomous economies has not been tested "when market integration turns international, a dynamic which is arguably even more problematic for small open economies” (Baldacchino, 2006a:855). The latter (2004) argues that developmental supports in the form of subsidies and trade preferences are unreliable interventionist tools, since not just the policies, but their protective effects, would probably have to be permanent to sustain the economic activity in question. This permanence is unlikely in an ever changing and ever more competitive world economy. Additionally, unlike most sovereign SIDS, SNIJs do not have the recourse of currency devaluation to make exports more attractive on the international market when competition increases or production conditions change unfavourably.

American Samoa, an unincorporated territory of the United States ${ }^{4}$ with a population of 68,000 in 2007, is one such example of a small sub-national island jurisdiction that has been able to nurture and maintain a thriving, although not entirely insulated, exportoriented industry. Its success has come as a result of a series of important features, including: its unique economic and political relationship with mainland United States, its locational advantage of proximity to the world's richest tuna fishery, and a supply of cheap labour power relative to the US mainland. This article critically examines how the policies of both the US government and the island territory have enabled American Samoa to capitalize on its geographical and economic advantages, facilitating its development as one of the largest sites of canned tuna production in the world. ${ }^{5}$

\footnotetext{
${ }^{4}$ American Samoa is an unincorporated and unorganized territory of the United States, administered through the Office of Insular Affairs in the Department of the Interior. It is represented in the US House of Representatives by one delegate (currently Eni Faleomavaga, the Representative since 1989). Until 2007, this position did not include voting rights, but was nevertheless central to American Samoa's representation in Congress since the delegate is able to sponsor and co-sponsor legislation. In 2007, the House extended limited voting rights to the five non-voting delegates (American Samoa, Guam, Puerto Rico, US Virgin Islands and the District of Columbia) in the Committee on the Whole House. The change is largely symbolic since it includes a provision that, in the event that the votes of any of the five delegates happen to be decisive, a new vote would be taken without them (H. Res. 78, 2007).

${ }^{5}$ Analysis of the dynamics of the global commodity chain in canned tuna, the US market for this product, and American Samoa's position therein are beyond the scope of this article, despite their obvious importance
} 


\section{Campling \& E. Havice}

The success of American Samoa's 'tuna economy' is not, however, without challenges. As such, American Samoa provides an important case study of how trade and economic policy influence how, where, and when industrial investment take place, and the stability of these investments in SNIJs. In contemplating if the SNIJ status of American Samoa is a viable response to the changing conditions of natural resource production and trade in the world economy, this analysis also provides insights on production opportunities and constraints for sovereign island states that share American Samoa's proximity to tuna rich waters, and that actively intersect (or aspire to do so) in different ways with the processing node of the global commodity chain in canned tuna. ${ }^{6}$

This article proceeds in three sections. The first provides an empirical sketch of the economic and trade policy relationships between American Samoa and the mainland United States and how they have served to sustain the accumulation strategies of firms involved in canned tuna production in Pago Pago (the territory's capital). The second section looks to the future. It identifies the most important threats and constraints to the commercial survival of the tuna economy in American Samoa; threats emanating both from within the SNIJ policy framework (such as changes to minimum wage policy and US free trade agreements with third countries), and from forces outside the immediate control of players in the American Samoan tuna economy (such as trade liberalization negotiations at the WTO and competitive pressures in the global tuna industry). In the concluding section we argue that, while strategic trade ties and associated policies with developed countries have been central to industrial development in some SNIJs (and in several SIDS that receive preferential access to EU and US markets), in the context of the contemporary world economy these policies are only one set of many factors that must be in place for internationally competitive industrial development. Indeed, while both SIDS and SNIJs should continue to utilize any strategic advantages available through relations with developed countries, they must plan for a time where the value of such benefits will be eroded, or completely eliminated, by a combination of trade liberalization and an enhanced competitiveness of larger developing countries vying for a piece of the tuna pie.

Finally, an important caveat in this article's coverage must be stressed. Given that the stocks of tuna species for canning in the West and Central Pacific Ocean are close to or fully exploited, the following analysis must be understood in the context of the need for significant improvements in the sustainability of tuna fisheries in the region. As such, any understanding of competition for market share must take into account the fact that total global markets for finished tuna products are unlikely to expand because of the underlying biological status of the resource itself. ${ }^{7}$

to a better understanding of the case at hand. Several important aspects are assessed in Campling et al. (2007), and in more detail with specific reference to American Samoa in Campling \& Havice (2007).

${ }^{6}$ In 2007, SIDS that were active sites of production of canned tuna and related products included: Fiji, Madagascar, Maldives, Marshall Islands, Mauritius, Papua New Guinea, Seychelles, Solomon Islands and Trinidad \& Tobago.

${ }^{7}$ For example, stocks of skipjack in the Western Pacific are estimated to be 'not fully' exploited, while those of yellowfin are 'fully' exploited. For albacore, the stock in the North Pacific is estimated to be 'over' exploited, while that in the South Pacific is assumed to be 'nearly fully' exploited (Hinton, 2007: 8). 


\section{Policy Interventions in the Tuna Canning Sector in American Samoa}

\section{Socio-economic Overview}

Post-World War Two, the West and Central Pacific Ocean (WCPO) became an important destination for distant water fleets (DWFs) targeting the regional tuna fisheries. Initially from Japan and the US, by the 1960s the DWFs active in the region had expanded to include vessels from South Korea, Taiwan and other Pacific Asian countries. The increase in fishing activity created a ready source of supply for tuna processing. Seizing this market opportunity, in 1954, Van Camp, a US fish processing and marketing company, built a new tuna cannery in Pago Pago. The move was especially strategic because American Samoa's capital is located near the tuna rich waters of the WCPO; also, in 1951, a US navy base had closed there, leaving behind a socio-economic void for the territory's citizens who were once employed by the military economy; a void that government was anxious to fill (Crocombe, 1995:273). Following Van Camp’s lead, in 1963 StarKist Samoa (SKS) set up tuna canning operations adjacent to the Van Camp plant.

At time of writing (end 2007), these two large processing plants continue to operate in American Samoa. One, operating in the former Van Camp facility is known locally as Samoa Packing, and internationally as Chicken of the Sea International (COSI). COSI is owned by Thai Union, headquartered in Thailand and, along with its Thai processing plants, is the world's second largest tuna processing company. The second plant in Pago Pago, SKS, is owned by StarKist Seafood, a subsidiary of Del Monte USA (see Table 1 for an overview of operations).

\section{Table 1: Overview of Tuna Canneries based in American Samoa}

\begin{tabular}{|c|c|c|c|c|c|}
\hline $\begin{array}{l}\text { Company/ } \\
\text { year set up } \\
\text { in Pago Pago }\end{array}$ & $\begin{array}{l}\text { Product (all } \\
\text { destined for } \\
\text { US Market) }\end{array}$ & $\begin{array}{ll}\text { Annual } & \text { raw } \\
\text { processing } & \\
\text { capacity } & \\
\text { (mt/annum) } & \end{array}$ & $\begin{array}{l}\text { Employment } \\
\text { (persons/ US\$3.21 } \mathrm{min} \\
\text { wage) }\end{array}$ & Ownership & Management \\
\hline $\begin{array}{l}\text { Star-Kist } \\
1963\end{array}$ & $\begin{array}{l}\text { Canned, } \\
\text { pet food, } \\
\text { limited } \\
\text { pouches } \\
\text { (interest in } \\
\text { expanding) }\end{array}$ & $\begin{array}{ll}1985: 80,000 & \\
2006: & \\
125,000 \quad \text { whole } \\
\text { round tuna/ } \\
10,000 \quad \text { frozen } \\
\text { loins* }\end{array}$ & $\begin{array}{l}\sim 2,500 \\
\text { Proposed adding } 200 \\
\text { jobs in facility upgrade }\end{array}$ & Del Monte US & US \\
\hline $\begin{array}{l}\text { Chicken of } \\
\text { the Sea } \\
1954\end{array}$ & $\begin{array}{l}\text { Canned, } \\
\text { pet food, } \\
\text { limited } \\
\text { pouches }\end{array}$ & $\begin{array}{l}\text { 1985: 75,000 } \\
\text { 2006: 90,000 whole } \\
\text { round tuna/ } \\
\text { 20,000 frozen loins }\end{array}$ & $\begin{array}{l}2,500 \\
\sim\end{array}$ & $\begin{array}{l}\text { Thai Union } \\
\text { (Thailand) }\end{array}$ & US \\
\hline
\end{tabular}

Sources: Doulman (1986:18); Bumble Bee, personal communication, 2006; Starkist, personal communication, 2006; Del Monte Foods Company (2005:9-10, 13-14).

* Tuna loins are butchered cooked meat which, vacuum-packed and frozen, are exported to higher cost sites of production (in this case the sole remaining cannery on the US mainland) to be defrosted and inserted directly into cans. The commercial logic here is that 'loining' constitutes circa $80 \%$ of the labour input in the production of a can of tuna. 


\section{Campling \& E. Havice}

The local and regional economic importance of the Pago Pago canneries cannot be overstated. ${ }^{8}$ The spin-off benefits of the processing facilities are abundant in American Samoa, and they also cascade through several other Pacific island economies. American Samoa's private sector economy is more than $80 \%$ dependent - directly and indirectly - on the two canneries, which employ over 5,000 people; that is, more than $45 \%$ of the workforce active in American Samoa (Flynn, 2005; Office of Congressman Faleomalvaega, 2007b; US Department of Labour, 2007). ${ }^{9}$ Economic benefits also emerge from shipyard repairs, bunkering and provisioning ships in the region; for example, it is estimated that US tuna boat owners previously contributed over US\$18 million per year to the economy of American Samoa through fuel purchases alone (Faleomavaega, 2002). ${ }^{10}$

Economic benefits from the Pago Pago canneries also abound throughout the region. Approximately $80 \%$ of cannery workers in American Samoa are from neighbouring independent Samoa (Associated Press, 2007), a particularly important economic boon since under- and unemployment are a serious problem in Samoa (and in most Pacific island countries). Indeed, Samoans who work in American Samoa (primarily in the two canneries) provided $10.8 \%$ of total remittances to Samoa in 2003/4: a value of US\$7.9 million (Central Bank of Samoa, 2005:47, 73). This is all the more important considering that remittances to Samoa from American Samoa alone were equivalent to the value of almost 60\% of Samoa's total exports in 2003/4 (Central Bank of Samoa, 2005:73).

American Samoa is also significant for small tuna exporting firms and fleets of locally based long liners in neighbouring Pacific island countries because it acts as an essential market outlet for catches of, primarily, albacore tuna (known as 'white meat' in the US). Without this outlet, the fate of these small firms is unsure at best. For example, $80 \%$ of the tuna caught in Samoa is destined for the American Samoa canneries (Pers. Communication, Samoan fisheries representatives, 2006). Additionally, Fijian firms regularly ship to Pago Pago, and a new and struggling firm in the small island of Niue has used the market outlet as well (Pers. Communication, Fiji and Niue industry

\footnotetext{
${ }^{8}$ Notably, the canneries in Pago Pago are not without their local costs. American Samoans point to significant environmental impact of the canneries on the fragile ecosystem, and the social tensions and economic stresses associated with immigrants that come to Pago Pago to work in the canneries. We thank an anonymous reviewer for this point, which was also raised in interviews with locals in Pago Pago. On the flip side, industry argues that the canneries are required to adhere to strict US environmental regulations on waste water, waste management and odour control; costs that their rivals in less regulated sites do not incur (Pers. Communication, US industry officials, 2006).

9 This figure reflects American Samoa's total workforce, which includes nationals as well as (Western) Samoans. Despite that the total population of American Samoa is 68,000, the civilian labour force is estimated to be only 17,600 people and civilian employment only 16,700 (US Department of Commerce, 2006). The tuna processing sector is the second largest source of employment to the American Samoan government which provides around 5,100 jobs (US Department of Labour, 2007). In 2006, each cannery was reporting a shortage of approximately 200 fish workers, plus the need for an additional 200 more workers to fill labour requirements to meet StarKist's planned expansion into tuna pouching. To meet these shortages, the American Samoa legislature passed legislation to form a guest-worker programme to enable (Western) Samoans to live and work in American Samoa on a temporary basis (Associated Press, 2007).

${ }^{10}$ However, the decline of the US fleet to only 14 vessels in 2007 means that these estimates need to be revised downwards. See below for a more detailed discussion of the US DWF. For more on the contribution of tuna fishing to American Samoa's economy prior to the US fleet decline, see Hamnet \& Pintz (1996).
} 
representatives, 2006). In short, American Samoa is a reliable sales outlet that offers consistent payment to suppliers. ${ }^{11}$ Additionally, the canneries pay between $80-95 \%$ of the price in advance: this contributes to cash flow stability for these small Pacific island firms.

Although the two canneries in American Samoa are some of the largest in the world, and their presence is valuable (and appreciated by many) in the region, their success is closely tied to continued economic and policy support from the mainland United States and the government of American Samoa. In light of the highly competitive nature of the global canned tuna industry from the 1980s onwards (and the concomitant crisis of profitability), ${ }^{12}$ this support is perhaps even more important today than when it was first implemented in the 1950s. The major policy interventions that continue to contribute to the viability of the tuna canning industry in the territory are outlined in the following.

\section{Securing Supply: American Samoa's Exemption from the Nicholson Act}

In 1953, the United States Bureau of Customs exempted American Samoa from the Nicholson Act which prohibited foreign vessels from landing or delivering fish in US ports. The exemption enables foreign vessels to supply the canneries in Pago Pago, and has been particularly relevant since the mid-1990s as the number of US vessels fishing in the region has precipitously declined (see discussion below). Without it, the canneries would simply be unable to procure sufficient fish to meet their operating needs. Indeed, although the canneries process more than 225,000 metric tons of fish per annum, in 2005, the US purse seine fleet caught less than 75,000 metric tons (WCPFC, 2006:109). A supply shortage would represent the death knell for the canneries, particularly given the need to achieve economies of scale to be competitive with lower cost sites of production in Southeast Asia.

\section{Securing the Market and fending off Competition: US Tariff Policy}

At the same time that American Samoa received an exemption from the Nicholson Act, the US Tariff Schedule was revised to allow tuna exports from American Samoa duty-free access to the US (Shug \& Galae'i, 1987:191-192). The policy revision was important in the 1950s to help the canneries in American Samoa gain access to the US market and also to give them a competitive edge against foreign producers at the time (such as those based in Japan). Duty free access to the US market has only become more important over the past 50 years as the number of firms in lower costs sites of production trying to access the US market, usually with the additional cost of paying a tariff, has increased.

The General Note 3 (a) program indicates that although territories such as American Samoa are outside the customs territory of the United States, their products receive duty-

${ }^{11}$ Additionally, the price of albacore is stabilized on a roughly quarterly basis through negotiations between the canneries and the Pacific Operating Committee (POC), a collective of Taiwanese long liners that fish in the WCPO. For more on this, see Campling et al. (2007: 361).

${ }^{12}$ See Bonanno \& Constance (1996) for an overview of these shifts. 
free access into US commerce if they meet the criterion of not more than $70 \%$ foreign component value (Harmonized Tariff Schedule of the United States, 2007). Canned tuna, regardless of the origin of the raw fish, easily meets this exemption because the fish in the finished canned product is only around $40 \%$ of total value. As a result, American Samoa receives zero-duty on exports of canned tuna to the US market, compared to $35 \%$ on tuna in oil and 6-12\% not in oil (generally water and brine) for all other exporters. Table 2 provides estimates on what the US processors would have to pay if they were charged duties to access the US market. While the benefits of annual savings of more than US\$50 million speak for themselves, what makes the duty free access most important is the protection that it gives the American Samoan canneries over lower cost exporters, such as those based in Thailand, that have to pay a duty. If Thailand is granted duty free access to the US, it will become an even fiercer competitor with American Samoa.

Table 2: Value of Duty Free Access to the US from American Samoa, 2003

\begin{tabular}{|l|l|c|c|}
\hline & $\begin{array}{l}\text { Total Shipped to } \\
\text { Mainland US } \\
\text { (US\$ Millions) }\end{array}$ & Tariff Rate & $\begin{array}{l}\text { Tariff Savings } \\
\text { (US\$ Millions) }\end{array}$ \\
\hline Tuna in Water & 408 & $6-12.5 \%$ & $40.5-45.8^{13}$ \\
\hline Tuna in Oil & 59.6 & $35 \%$ & 20.8 \\
\hline & & & Total: $\mathbf{5 2 . 3 - 5 7 . 6}$ \\
\hline
\end{tabular}

Source: Flynn (2005: Section VI).

Duty free treatment is all the more important considering that a major focus of COSI and StarKist production in Pago Pago is canned albacore. Since albacore is a higher value fish, ${ }^{14}$ the impact of the duty structure is proportionately higher on competitors' canned

\footnotetext{
${ }^{13}$ US duties for canned tuna in water depend on a quota that limits imports from any single country to no more than $4.8 \%$ of the total tuna in air tight containers consumed in the previous year. The tariff rate for canned tuna 'not in oil' (e.g., in brine or spring water) shifts from 6 to $12.5 \%$ when the tariff quota is full. In Table 2 the lower end of the range assumes all of the US\$80.7 million of imports below quota were from processors in American Samoa and were dutiable at only 6\%. The higher end of the range assumes that none of these imports were below quota. Calculations for the lower range: Assume all below-quota imports are from the American Samoa processors. Then multiply $6 \%$ times the US\$80.7 million quota, to get US\$4.8 million in below quota duties. Subtract US\$80.7 million from US\$367 million total imports to get US\$286.3 million in imports above quota at $12.5 \%$ (or US\$35.7 million in above-quota duties). Under this assumption, total duties for canned tuna not in oil are approximately US\$40 million. On the other hand, if it were assumed that none of the imports were shipped in time to benefit from the below-quota tariff, there would be a flat $12.5 \%$ above-quota duty for total imports of US\$367 million, or US\$45.8 million. Given the large market share that StarKist and Chicken of the Sea have of the US market, it is likely that much of their shipments would come in under quota.

${ }^{14}$ According to industry officials, in American Samoa in May 2006, skipjack was US\$800/metric ton, while Albacore was US\$2,900/metric ton. However, it should be noted that this inter-species price differential fluctuates over time and as such is not always quite so extreme.

${ }^{15}$ Tuna in pouches from Ecuador have duty free access to the US market as part of the Andean Trade Preferences Act, the future of which is uncertain. See below for a more complete discussion.
} 
albacore production. These benefits are compounded by the fact that since albacore are 2-3 times bigger than other species that are canned (mainly skipjack), labour costs are less because the 'recovery rates' are higher: it is more efficient to loin one large albacore than 2-3 small skipjack (Pers. communication, US tuna industry representative, 2006).

Thailand, the Philippines and Ecuador in particular are playing an increasingly important role in supplying the US market with canned, and more recently pouched, tuna. ${ }^{15}$ Notably, despite American Samoa's tariff preference, firms based in lower cost production sites are able to compete with American Samoa in the US market even though they must pay tariffs and survive in the context of the drastically reduced price of canned tuna at point of retail. ${ }^{16}$ In fact, even with the extra $6-35 \%$ that exporters pay to access the US market, they are actually driving price downwards because of their lower overheads (Lischewski, 2006).

\section{Attracting Manufacturing Capital: Tax Policy}

In addition to preferential access to the US market and the exemption to the Nicholson Act, the canneries in American Samoa also benefit from a series of tax exemptions from both the US and the American Samoan governments.

By far the most commercially significant of these is Section 936 of the Internal Revenue Act of the US federal government. It provides domestic corporations with a tax credit equal to the taxable income from the active conduct of a trade or business in the US territories (I.R.C §936, 1986). Thus, income derived from cannery operations in American Samoa is effectively exempted from US corporate income taxes, a saving of approximately US\$10million annually (Office of Congressman Flaeomavaega, 2007c). Section 936 officially expired on 1 January 2006; however, a one-year extension was negotiated in Congress. During 2006/7, a great deal of uncertainty over the future of the tax credit, and thus, the future of the canneries, ensued, with concern that the loss of Section 936 could be damaging enough to spur the canneries to seek processing sites in other areas.

Much to the relief of the American Samoan government and those employed by the canneries, Section 30A, which offers the same benefits as 936 but gives them a new name to avoid the political struggles associated with '936', has extended the tax exemptions for one more year [Tax Relief and Health Care Act of 2006, Pub. L. No. 109-432, § 119, Stat. 30A (1986) (amended, 2006)]. While this is an extremely important benefit for the canneries, since the tax exemptions are scheduled to expire once more on December 31, 2007, the American Samoan Congressman is left to negotiate yet again for a more permanent extension of the tax relief; indeed, he has proposed a bill that would extend the tax credits for another 10 years. It is unknown if the economic viability of the canneries

\footnotetext{
${ }^{16}$ When adjusted for inflation, canned tuna prices in the US have declined by $68 \%$ since 1982 (Catarci, 2004:48). The impact of declining prices has been compounded by increasing costs of labour, fuel and cans.

${ }^{17}$ To re-iterate the note above, analyzing global production-consumption linkages in canned tuna is essential for understanding trends, dynamics and processes affecting the industry based in American Samoa. This is beyond this article's scope; but we wish to alert readers to such key aspects (see Campling \& Havice, 2007).
} 


\section{Campling \& E. Havice}

rests on the continuation of Section 30A, or if the two firms are simply scaremongering to maintain higher profits. Despite this uncertainty, American Samoa continues to fight for 30A, and for all other benefits that will keep the plants from leaving Pago Pago for lower cost sites of production.

In addition to benefits from the US federal government, the government of American Samoa offers a series of corporate tax benefits to the canneries. These include a reduced corporate income tax, tax exemptions for purchase of raw materials and inputs to the canning process, a graduated tax exemption on corporate income taxes, employee tax benefits, and tax exemptions for owners and operators of vessels that supply the canneries. In addition, tax payment flexibilities are applied if a cannery's income falls below a certain level due to natural events, or to the expiration of the 936 benefits noted above (Pers. Communication, American Samoan government official, 2006; American Samoa Code Annotated, 2007).

\section{Summary}

The exemption from the Nicholson Act, the revisions to the tariff code, and tax exemptions demonstrate how American Samoa's status as a SNIJ has been a central factor in the tuna industry's development and growth. While the sovereign policy decisions, such as domestic tax exemptions, have also been helpful to the industry, they would not have been enough to develop the industry, and are not enough to maintain it alone. In short, SNIJ status has been essential for industrial development in American Samoa. For the rest of the SIDS in the region seeking a place in the global tuna industry without strategic relationships with developed countries and markets, the challenges of capitalizing on comparative advantages in a globally competitive environment are greater still.

But: is SNIJ status enough to sustain the long-term commercial survival of the sector? And what lessons does American Samoa's experience lend to the experiences of both SNIJs and sovereign SIDS seeking to compete in global manufacturing industries? Focusing on the US market, the following section gives an overview of the major challenges facing Pago Pago's tuna canning industry. ${ }^{17}$ This context helps to elucidate why the benefits outlined above are critical to the success of the canneries, and to demonstrate the challenges that the Pago Pago canneries face in competing for their market share in an increasingly competitive (and global) production environment. 


\section{Major Threats to American Samoa's Competitiveness in the Global Tuna Industry}

The global production-consumption of canned tuna is not stagnant. Rather, it is constantly evolving, both responding to, and driving, policy and industrial change. While processors seek to secure their current interests, they are at once planning for their commercial survival by monitoring policy and market dynamics and adjusting their corporate strategies accordingly. Currently, three market dynamics are in flux, and their outcomes have real potential to override industrial development in Pago Pago. These are, in turn: preference erosion, the decline of the US DWF, and the role of minimum wage legislation.

\section{Trade Preference Erosion}

Perhaps the most significant threat to American Samoa's continued leadership in the US canned tuna market, is the global march towards trade liberalization. As the World Trade Organization slowly inches towards international reduction of tariffs, ${ }^{18}$ and individual countries gallop towards similar objectives through bilateral and regional free trade agreements (FTAs), American Samoa's duty free access to the US market becomes less and less commercially valuable to the canneries. As noted above, the canneries currently enjoy a tariff preference of between $6 \%$ and 35\% (depending on the product and its origin) over foreign competitors; however, US FTA negotiations with Ecuador and Thailand in particular $^{19}$ (both of which have encountered serious stalls) have the capacity to derail the competitive value of these preferences by offering improved market access to these low cost competitors.

The global nature of the two multinational corporations with plants in Pago Pago, and the third major US processor, Bumble Bee, which does not have a stake in American Samoa, complicates the impact and the outcome of tariff reductions. Indeed, on the issue of tariffs, the lobbying cohesiveness of the US canning sector is split, reflecting the distinct strategies of the individual firms. As a result, there is no consensus among the three processors on the costs and benefits of the various FTAs; and no one strong voice protecting the interests of Pago Pago. On the one hand, if the preferences remain intact and no further FTAs are

\footnotetext{
${ }^{18}$ Efforts to reduce tariffs at the World Trade Organization have encountered serious difficulties in the current Doha Round of trade negotiations. As at November 2007, the state of these negotiations was fragile at best. Compounding the difficulty of achieving an agreement at the WTO, President Bush's 'Fast Track' authority, which dramatically eases the process of approving trade agreements by allowing the US Congress to either accept or reject trade text, but not allowing it to make any changes, expired on 30 June 2007. This means that highly contentious WTO agreements (when and if they are agreed upon) will be subject to the scrutiny of US Congress members, many of whom have constituents who perceive that they stand to lose from the expansion of trade liberalization.

${ }^{19}$ The US is also exploring the possibility of entering into an FTA with the Philippines, the second largest exporter of canned tuna products to the United States.

${ }^{20}$ Currently, the ATPA only grants duty free access for tuna in pouches, not cans, destined for the US market. The uncertain future of ATPA has led StarKist to prepare to move their pouch sector to American Samoa (Associated Press, 2007). The status of ATPA is not the only issue facing the Ecuador plants. It seems that Ecuador may also be limited by lack of adequate raw materials if poor catch rates continue in the Eastern Tropical Pacific as a result of overfishing (Pers. Communication, US fishing industry representative, 2007).
} 


\section{Campling \& E. Havice}

concluded, COSI and SKS in American Samoa retain their competitive edge over foreign competitors. On the other hand, both COSI and SKS's parent companies have investments in lower cost sites of production and are working to conclude FTAs that will provide dutyfree access to the US market for these plants. This has led to a complex nexus of alliances and interests, all of which are to some extent prey to the forces of global political economy, but which will ultimately dictate the competitiveness of production in various sites.

For example, StarKist has significant vested interests in Ecuador. Thus, they actively lobbied for more extensive market access for tuna products through the Andean Trade Preference Act (ATPA). ${ }^{20}$ If actualized, broader market access for tuna products in the ATPA (and the Ecuador-US FTA negotiations) will undermine the economic viability of StarKist's Pago Pago plant. The future of the ATPA is uncertain. After expiring on 31 December 2006, a six month extension of the agreement was subsequently granted, and at the end of June 2007, the agreement was extended for another eight months until 29 February 2008 [H.R. 1830 (2007) (Engrossed as Agreed to or Passed by House)].

On the same account, because Chicken of the Sea is owned by Thai capital, it often represents the interests of Thailand. In the debate on the ATPA, the Southeast Asian countries want to limit competition from possible duty-free Andean products on the US market, so they have supported American Samoa and Chicken of the Sea in their efforts to curb market access for tuna within the ATPA, as well as other US trade agreements with Central American and Caribbean countries. At the same time, COSI supports market access for tuna as part of ongoing US-Thai FTA negotiations. This is because duty free access into the US is in the interests of its parent company, Thai Union, despite the fact that this might not be in the interests of the COSI cannery in American Samoa.

Surprisingly, the only major US brand without investment in Pago Pago is the most consistent ally of this SNIJ on tuna market access in US FTAs. Since Bumble Bee owns the last remaining canned tuna plants on the US mainland and in Puerto Rico, its objective is to maximize the length of time that tariff protection secures the commercial viability of these investments.

Significantly, each of the 'big-three' US tuna processing companies, including Bumble Bee, have substantial interests (including medium-term supply contracts) in Thailand. So, despite their variable interests across the board, duty free access for Thailand might be something that they can all agree upon in the long-run.

In short, although the proliferation of bilateral and regional trade agreements means that American Samoa's preferences will be eroded over time, the processing companies currently operational in Pago Pago already have globally diversified investments in production and sources of finished product. Thus, if preferences are eroded, the end of the American Samoa canneries will not be the end of COSI or StarKist. Rather, they are prepared to move their operations to more cost-effective sites. According to industry 
officials, the canneries are doing monthly calculations of the costs and benefits of working in American Samoa, and waiting to see what combination of events will be the tipping point that makes it too costly to do business in Pago Pago (Pers. Communication, US industry representatives, 2006).

\section{Decline of the US DWF}

A second problem for the canneries is the security of their supply, which has been reduced by a combination of increased market outlets (and therefore competition) for raw materials and the dramatic decline in size of the US purse seine fleet, traditionally a consistent source of supply for Pago Pago canneries. The number of US flagged purse seiners active in the Western and Central Pacific Ocean, and therefore supplying American Samoa, has declined from 62 in 1983, to just 11 in mid-2006, and rebounded slightly in 2007 to 14 vessels (SPC, 2004; Forum Fisheries Agency Database). This has reduced the steady supply of raw material to the canneries and cut into local spin-off benefits, such as bunkering and the provision of goods and services to vessels and crew. As a result, Pago Pago no longer has a captive fleet and has been forced to purchase more supply from trading companies that offload carrier vessels at the canneries' docks. This has proven to be expensive because the sea-freight costs are incorporated into the price of fish, a cost not incurred when the US vessels offload directly at the docks (Pers. Communication, US industry representative, 2006).

The US canneries are however leading an effort to finance rebuilding the US tuna fleet. As a result, in 2007, the fleet has rebounded from 11 to 14 vessels, with at least five more vessels expected to buy licenses to operate in the WCPO by end-2007. ${ }^{21}$ While growth in the US tuna fleet would certainly benefit the canneries in American Samoa by helping to secure supply, the growth is not contingent upon the presence of canneries in Pago Pago, rather it is a strategic move by multinational processing companies to control more of the production line as supply constraints become tighter in an era of declining resources and increased competition for raw materials.

\section{Comparative wage rates}

Although American Samoa has been able to make use of economic and industrial policy interventions, it still faces competition with firms based in lower cost sites of production. Indeed, many of American Samoa's competitors have significantly lower operational expenses, one of the most significant of which is labour costs.

\footnotetext{
${ }^{21}$ This effort, led by the US processing sector, proposes entering into joint ventures (51\%-49\% ownership) with Taiwanese capital to purchase Taiwanese-built vessels (new and used), which are much less expensive and much more fuel efficient than the aging US fleet. (See Campling et al. (2007: 153-163, 280-282).

22 The US\$3.21 minimum wage rate is regulated by the Code of Federal Regulations Pertaining to ESA, 29 CFR 697.2.
} 


\section{Campling \& E. Havice}

American Samoa's minimum wage rate is significantly lower than that of the mainland US, but it is still comparatively higher than the wage rates of its main competitors. Intensifying concern about operating costs in Pago Pago, new minimum wage legislation passed in the US in 2007 requires American Samoa to incrementally increase wages from their current rate of US\$3.21 per hour ${ }^{22}$ to more than US\$7.00 per hour (Weisman, 2007).

In 2001, the average hourly wage (including benefits) for workers at the Pago Pago canneries was US\$4.01. When compared to Ecuador (US\$0.77/hour), the Philippines (US\$0.67/hour), Thailand (US\$0.66/hour) or Indonesia (US\$0.16/hour), the wage differential is substantial (Prehearing statement of COS Samoa Packing Company, 2001; Corey \& Bablua 2002:7). A basic calculation (which does not factor in different levels of capital efficiency or labour productivity) illustrates the point: assuming a total labour force of 5,000 workers doing two, 10-hour shifts per day for five days per week (annual days = $250),{ }^{23}$ basic annual wage costs in American Samoa are US\$50 million, while in Thailand they are only US\$8.25 million. When the contemplated minimum-wage increases to US\$7.25 in American Samoa come into force, wages will jump to a staggering US\$91 million (more than 1,000\% increase from the cost of Thai labour). Notably, although Thai wage costs are far more competitive than those in American Samoa, Thai companies have begun to outsource their processing activities to plants in China and Vietnam to save on labour costs (Pers. Communication, Thai industry representatives, 2006).

The minimum wage bill that was passed by Congress required American Samoa to increase the current minimum wage by US $\$ 0.50$ per hour 60 days after the enactment of the legislation, and each year thereafter until the American Samoan minimum wage reached that of the mainland United States [H.R. $1591 \S 7102$ (2007) (Engrossed as Agreed to or Passed by House)]. From a public policy perspective, the objectives of a minimum wage increase are clear; however, if the minimum wage rises at a rate that exceeds labour productivity gains, the wage increase has the potential to drive unemployment by giving the canneries one more reason to close their doors. ${ }^{24}$ The law does include a provision directing the US Department of Labour to undertake and complete a study on the economic impact of the minimum wage increase in American Samoa within the first eight months of the increase. The findings of the study are perhaps the only recourse that American Samoa will have in ending the escalator clause that could drive the canneries out of Pago Pago.

American Samoa's dilemma of trying to maintain competitiveness while trying to generate employment was neatly demonstrated by the Vice President of Del Monte's (StarKist's parent company) response to the minimum wage increase. Upon hearing news of the minimum wage increase, he announced that StarKist's commitment to expanding production to include pouches was put on hold - a venture that was slated to occur in July

\footnotetext{
${ }^{23}$ Many processing plants, especially the largest, such as those in Thailand and American Samoa run two, 10hour shifts. The canneries in American Samoa each employ approximately 2,500 workers over two shifts. The largest Thai canneries employ between 5,000 and 6,000 workers over two shifts (Pers. Communication, industry representatives, 2006; Associated Press, 2007).

${ }^{24}$ We thank an anonymous reviewer for this point.
} 
2007 and would have created more than 200 jobs in the factories. In fact, the expansion project as a whole is now in jeopardy (Office of Congressman Faleomavaega, 2007c).

\section{Conclusions and Future Scenarios}

This article has used the case study of the American Samoa as a 'tuna economy' to demonstrate the ways the industrial development in a SNIJ can both capitalize on, and be challenged by, government policies that influence trade and production. In particular, in keeping with the findings of recent studies on economic development in SNIJs, it has demonstrated that economic and policy relations with developed economy governments can be a central factor in developing and maintaining viable industrialization strategies that build upon an economy's existing advantages. The article has served to broaden this literature by demonstrating that despite the benefits of SNIJ status, the logic of 'competitiveness' in contemporary capitalism has made the canneries in Pago Pago, and the local socio-economies that depend on them, subject to a high degree of uncertainty. In this light, SNIJs must prepare for a future where their strategic benefits with developed countries lose at least some of their significance. Since SNIJs have also been found to have more economic success than many of their sovereign island counterparts, it follows that sovereign SIDS - which face the same competitive challenges in contemporary capitalism and the international trade regime, but do not benefit from SNIJ status - will continue to face significant development challenges as they seek to integrate into the world economy.

Given the current status of production, the structure of the US market and the uncertain outcome of the multiple policy debates that influence the tuna industry in particular, there are three potential outcomes for the canneries in American Samoa. These options are not necessarily mutually exclusive, and potentially reflect a continuum of adaptation to the global market. Each of these three scenarios will reflect changes in international trade policy, and will in turn, exert their own impact on the US-centred commodity chain in canned tuna, and importantly, on the economy of American Samoa and tuna-related economic activities in the region.

First, the status quo might continue indefinitely. In this (unlikely) case, the employment and spin-off benefits of the canneries will continue, including remittances to Samoa and a stable market outlet for small Pacific island firms. Certainly, for this to be the case for the long-term, several variables will have to align, including the continuation of trade preferences and tax breaks from the mainland US and the government of American Samoa. Additional benefits, such as the rebuilding of the US fleet and an inflow of capital investment into the canneries through the proposed expansion into pouch production, will also help to keep the canneries operational for as long as is commercially viable.

Second, the canneries can stop processing fish in-house and can shift to become canningonly plants (with loins imported from lower cost sites of production). Initially, this shift would negatively impact the employment of (Western) Samoans in Pago Pago. The conversion of a full-scale cannery into a canner of loins imported from elsewhere will eliminate around $80 \%$ of the labour input. This would also have a negative impact for 


\section{Campling \& E. Havice}

small Pacific island firms, which would likely lose this convenient outlet for their whole fish, or have to take a much lower price to get their relatively small quantities to a processing outlet. Certainly, an increase in the mandatory minimum wage in American Samoa could spur this change to save on labour costs.

Finally, if several policy aspects fall together at once, such as the elimination of preferences, the cessation of the tax benefits from the US, and an increase in the minimum wage, the canneries would certainly collapse under the competitive (and strategic) pressures of the global tuna trade, and relocate their processing to lower cost sites of production. As American Samoa is, in essence, a one-industry economy, the territory would have to adapt, or deteriorate rapidly. The resulting high unemployment and economic decline in American Samoa and mass return of migrant labour to Samoa would have associated negative implications for political stability and social and economic security in both locations.

Immediate and more long-term alternative strategies for the people of American Samoa present themselves through their links to mainland US. As US nationals, they are eligible to live and work on the mainland without restriction, and may well move there in search of employment. The US military also remains an important source of employment for American Samoans, an option available to US citizens, nationals and non-citizens alike. ${ }^{25}$

Beyond impacts on the citizens of American Samoa, the closure of the canneries might also prove negative for the tuna firms in the region that have relied on them as a significant commercial outlet. However, the market void associated with the canneries' collapse could also have the potential of opening sources of supply for existing and new processing plants in other Pacific island countries, although they too face the complex challenges of competing in the world economy.

\section{Acknowledgements}

We would like to thank three anonymous peer reviewers, Chris Read, Kristin Reed, Helga Josupeit and an experienced representative of the tuna industry for invaluable comments and inputs on an earlier version of this article. We also thank James Duff and Jason Malinsky for assistance with legal citations. The usual disclaimer applies.

\footnotetext{
${ }^{25}$ In 2005 alone, more than 400 American Samoans were recruited to the US Army (Potter, 2006); but not without risk. Seventeen American Samoans have been killed in combat or in support roles in the US-led wars in Afghanistan and Iraq between August 2003 and November 2007. This gives American Samoans a higher death rate per capita than citizens from elsewhere in the US or any of its other territories (Department of Insular Affairs, 2007; Fischer et al., 2007; Scharnberg, 2007).
} 


\section{References}

American Samoa Code Annotated (2007), Title 11, Ch. 16, §11.1601-11.1612.

Amsden, A. (1989) Asia's Next Giant: South Korea and Late Industrialization, Oxford, Oxford University Press.

Armstrong, H.W. \& Read, R. (2000) 'Comparing the Economic Performance of Dependent Territories and Sovereign Microstates’ Economic Development and Cultural Change, Vol. 48, No. 2, pp. 285-306.

Armstrong, H.W. \& Read, R. (2002) 'The Phantom of Liberty? Economic Growth and the Vulnerability of Small States' Journal of International Development, Vol. 14, No. 3, pp. 435-458.

Armstrong, H.W. \& Read, R. (2006) 'Geographical 'Handicaps' and Small States: Some Implications for the Pacific from a Global Perspective’, Asia Pacific Viewpoint, Vol. 47, No. 1, pp. 79-92.

Associated Press (2007) 'American Samoa Tuna Canneries spur Guest Worker Law: Del Monte Foods Inc. and Chicken of the Sea are recruiting Workers', Honolulu Star Bulletin, Honolulu, 26 May.

Baldacchino, G. (1998) 'The Other Way Round: Manufacturing as an Extension Of Services In Small Island States’, Asia Pacific Viewpoint, Vol. 39, No. 3, pp. 267-279.

Baldacchino, G. (2006a) 'Innovative Development Strategies from Non-sovereign Island Jurisdictions? A Global Review of Economic Policy and Governance Practices', World Development, Vol. 34, No. 5, pp. 852-867.

Baldacchino, G. (2006b) 'Managing the Hinterland Beyond: Two Ideal-Type Strategies of Economic Development for Small Island Territories’, Asia Pacific Viewpoint, Vol. 47, No. 1, pp. 45-60.

Baldacchino, G. (2006c) 'Exploring Sub-National Island Jurisdictions: An Editorial Introduction', The Round Table: Commonwealth Journal of International Affairs, Vol. 95, No. 386, pp. 487-502.

Betram, G. (2004) 'On the Convergence of Small Island Economies with their Metropolitan Patrons’, World Development, Vol. 32, No. 2, pp. 343-364.

Bonanno, A. \& Constance, D (1996) Caught in the Net: The Global Tuna Industry, Environmentalism and the State, Lawrence KS, University Press of Kansas.

Campling, L. (2006) 'A Critical Political Economy of the Small Island Developing States Concept: South-South Cooperation for Island Citizens?' Journal of Developing Societies, Vol. 22, No. 3, pp. 235-285.

Campling, L. \& Rosalie, M. (2006) 'Sustaining Social Development in a Small Island Developing State: The Case of Seychelles’, Sustainable Development, Vol. 14, No 1, pp. 115-125. 
Campling, L. \& Havice, E. (2007) 'The Marginalization of Small Remote Economies in Global Capitalism: American Samoa, Economies of Scale and the Global Commodity Chain in Canned Tuna', unpublished mimeo.

Campling, L., Havice, E. \& Ram-Bidesi, V. (2007) Pacific Island Countries, The Global Tuna Industry and the International Trade Regime: A Guidebook, Honiara, Solomon Islands, Forum Fisheries Agency, www.ffa.int/node/891.

Catarci, C. (2004) The World Tuna Industry: An Analysis of Imports and Prices, and of their Combined Impact on Catches and Tuna Fishing Capacity, Rome, Food and Agricultural Organization.

Central Bank of Samoa (2005) Bulletin June 2005, XX: 2, Apia, Samoa.

Chang, H-J. (2004) Kicking Away the Ladder: Development Strategy in Historical Perspective, London, Anthem Press.

Coan, A.L., Sakagawa, G.T., Prescott, D., Williams, P., Staish, K. \& Yamasaki, G. (2000) The 1999 U.S. Central-Western Pacific Tropical Tuna Purse Seine Fishery Administrative Report LJ-00-10, Annual Meeting of Parties to the South Pacific Regional Tuna Treaty, Niue.

Connors Bros. (2006) Income Fund 2005 Annual Report, Markham, Connors Bros.

Crocombe, R. (1995) The Pacific Islands and the USA, Suva, Institute of Pacific Studies, USP and Honolulu HI, East-West Center.

Del Monte Foods Company (2005) Form 10-K: Report to the United States Securities and Exchange Commission for the Fiscal Year Ended May 1, 2005.

Demas, W. (1965) The Economics of Development in Small Countries with Special Reference to the Caribbean, Montreal, Québec, Canada, McGill University Press.

Doulman, D.J. (1986) 'Options for U.S. Fisheries Investment in the Pacific Islands', Mimeo, Pacific Islands Development Program, Honolulu, East-West Center, pp. 1-25.

Fischer, H., Klarman, K. \& Oboroceanu, M-J. (2007) American War and Military Operations Casualties: Lists and Statistics, CRS Report for Congress (Updated June 29, 2007), www.fas.org/sgp/crs/natsec/RL32492.pdf

Flynn, N.M. (2005) Economic Report: The Minimum Wage in American Samoa, 2005, Washington DC, Department of Labour.

Hache, J.-D. (1998) 'Towards a Political Approach to the Island Question' in G. Baldacchino \& R. Greenwood (eds.) Competing Strategies of Socio-Economic Development for Small Islands, Charlottetown, Canada, Institute of Island Studies, pp. 3168.

Hamnet, M. \& Pintz, W. (1996) 'The Contribution of Tuna Fishing and Trans-shipment to the Economies of American Samoa, the Commonwealth of the Northern Mariana Islands and Guam', JIMAR Contribution (6-303), Honolulu HI, Joint Institute for Marine and Atmospheric Research.

Hinton, M.G. (2007) 'Global Tuna Resources: Stock Status, Fishing Capacity, Management, Sustainability and Prospects' in S. Subasinghe, S. Pawiro \& S.M. 
Anthonysamy (eds.) Proceedings of the Tuna 2006 Bangkok $9^{\text {th }}$ World Tuna Trade Conference, 25-27 May 2006, INFOFISH.

H.R. 78 (2007) (In Effect in the House).

H.R. 1591 § 7102 (2007) (Engrossed as Agreed to or Passed by House).

H.R. 1830 (2007) (Engrossed as Agreed to or Passed by House).

I.R.C. § 936 (1986).

Josupeit, H. (2006) 'Tuna Market Report - US August 2006’, Rome, GLOBEFISH/FAO.

Lischewski, C. (2006) 'The US Market: Shelf Stable Seafood', paper presented at the INFOFISH Tuna 2006 Conference, 25-27 May 2006, Bangkok, Thailand.

McElroy, J.L. \& Pearce, K. (2006) 'The advantages of political affiliation: Dependent and Independent Small Island Profiles' The Round Table: Commonwealth Journal of International Affairs, Vol. 95, No. 386, pp. 529-539.

Office of Congressman Faleomavaega (2002) 'Andean Trade Agreement Passes House with Revisions on Tuna’, Washington, D.C., Press Release 26 July.

Office of Congressman Faleomavaega (2007a) 'Minimum Wage Bill (H.R. 1591) Proposes Increase of 50 Cents Per Hour for American Samoa and CNMI Workers', Washington, D.C., Press Release, 24 April.

Office of Congressman Faleomavaega (2007b) 'Faleomavaega Responds to Latest Developments Regarding Minimum Wage', Washington DC, Press Release, 11 May.

Office of Congressman Faleomavaega (2007c) 'Faleomavaega Responds to StarKist's Threats Regarding Minimum Wage’, Washington DC, Press Release, 11 May.

Office of Insular Affairs (2007) 'Fallen Heroes in the War on Terror from OIA's Insular Areas', www.doi.gov/oia/Firstpginfo/islanders_in_the_military/heroes.html.

Poirine, B. (1998) 'Should we love or hate MIRAB?' The Contemporary Pacific, Vol. 10, No. 1, pp. 65-105.

Potter, M. (2006) 'Eager to Serve in American Samoa: But that Strong Civic Duty Often Exacts the Heaviest Price’, NBC News, www.msnbc.msn.com/id/11537737/from/RSS/.

Sabatini, P. \& Josupeit, H. (2006) Tuna Commodity Update, Rome, GlobeFish/FAO.

Scharnberg, K. (2007) 'Young Samoans Have Little Choice but to Enlist', The Honolulu Advertiser, Honolulu, Local News.

Shug, D.M. \& Galea'I, A.P. (1987) 'American Samoa: The Tuna Industry and the Economy' in D.J. Doulman (ed.) Tuna Issues and Perspectives in the Pacific Islands Region, Honolulu HI, East-West Center, pp.191-202.

SPC (2004) Secretariat of the Pacific Community Tuna Fishery Yearbook 2003, Noumea, South Pacific Commission.

Tax Relief and Health Care Act of 2006, Pub. L. No. 109-432, § 119, Stat. 30A (1986) (amended, 2006). 
US Department of Labour (2007) Economic Report: The Minimum Wage in American Samoa, 2007, Employment Standards Administration, Wage and Hour Division. Washington DC, US Department of Labour.

US Department of Commerce (2004) Population \& Housing Profile: 2000 Census of Population \& Housing, American Samoa, www.census.gov/prod/cen2000/island/ASprofile.pdf.

USITC (2007) 'Products of Insular Possessions', in Harmonized Tariff Schedule of the United States (2007), General Note 3(a)(iv)(A), United States International Trade Commission, Publication No. 3902.

Wade, R. (1990) Governing the Market: Economic Theory and the Role of Government in East Asian Industrialization, Princeton, New Jersey: Princeton University Press.

WCPFC (2006) Western and Central Pacific Fisheries Commission Tuna Fishery Yearbook, T.A. Lawson (ed.) Noumea, French Caledonia, Western and Central Pacific Fisheries Commission.

Weisman, J. (2007) 'Minimum-Wage Bill Stirs Controversy in Pacific Islands', The Washington Post, Washington DC, A04.

Winters, L.A. (2005) 'Policy Challenges for Small Economies in a Globalizing World' in S. Chand (ed.) Pacific Islands Regional Integration and Governance, Canberra, Australian National University Press and Asia Pacific Press, pp. 7-25.

Winters, L.A. \& Martins, P.M.G. (2004) 'When Comparative Advantage is not Enough: Business Costs in Small Remote Economies', World Trade Review, Vol. 3, No. 3, pp. 347383. 